\title{
6。透析療法における血液透析装置通信プロトコール 共通化のバージョンアップ（案）について
}

一第 48 回日本透析医学会ワークショップより一

\author{
芝本隆上野信一井村卓川村正喜 \\ 秋 葉隆 \\ 日本透析医学会学術委員会コンピュータ化検討小委員会 \\ 通信共通化ワーキンググループ
}

はじめに

日本透析医学会学術委員会（透析医療におけるコン ピュータ化検討小委員会）は日本医療器材工業会（旧 工藏協）と協力して血液透析装置の一括モニタリング を目的に共通通信プロトコールを開発した。今回は開 発したシステムを 5 年間評価し，本システムに追加す ベき項目や現状ニーズに合致したシステムへ改良する 運びとなった。そこで改良される共通通信プロトコー ル（案）について報告する。

\section{I．現状の共通通信プロトコールと市販中央監 視システム}

現状の共通通信プロトコール仕様概要は, コン ピュータからのサンプリング信号 5 秒以上で装置はコ ンピュータへ情報を送信する。通信項目は装置情報と 警報を合わせた 20 項目を持つ，である。

一方，市販される中央監視システムでは，体重計か らの情報により透析装置(あらかじめ適正体重を入力) は除水量を自動的に設定する。また，水処理装置情報 や自動血圧計などの情報管理が同一システムで行える (ここでは中央監視システムと透析装置は同一メー カーが絶対条件)。さらに，市販される中央監視システ ムの通信項目（自動設定項目と自動プログラム設定項 目に大別）は共通通信プロトコールに比べ遙かに多い 情報量を有する。

\section{II. バージョンアップ (案) について}

\section{1. 通信仕様}

現状の共通通信プロトコール仕様書の，「II。通信プ ロトコール」,「1。通信接続仕様」,「(1)通信仕様」, 「1）通信方式」の項目では RS232C 準拠としていた が, 情報量の増加を考え容量の大きい RS485 準拠を追 加した。 また,「( 2 )の接続コネクター仕様」は, 絶縁 型または RJ45 相当の項目が追加され, 絶縁対策と LAN を初めて採用し安全性を考慮した。さらに項目 「( 3 ) デー夕要求信号」は現在の 5 秒から「2 秒以上と する」に変更した。

\section{2. 送信データ}

送信データでは, 透析装置が「透析中か, または透 析以外の状態」かの識別項を新たに追加する。また， 治療の多様化に適合するためHDモードの他に $\lceil\mathrm{ECUM}\rfloor,\lceil\mathrm{HDF}\rfloor,\lceil\mathrm{HF}\rfloor の$ 治療モードの設定を可能

表 共通通信プロトコールの追加通信項目

\begin{tabular}{|c|c|c|c|c|}
\hline NO. & 名称 & 識別コード & Byte 数 & 単位 \\
\hline 21 & 治療プラグ & “M” & HEX 1 Byte & \\
\hline 22 & 治療モード & "N" & HEX 1 Byte & \\
\hline 23 & 補液目標値 & "O" & HEX 5 Byte & L \\
\hline 24 & 補液経過值 & "P" & HEX 5 Byte & L \\
\hline 25 & 補液速度 & “Q” & HEX 5 Byte & $\mathrm{L} / \mathrm{hr}$ \\
\hline 26 & 補液温度 & " $\mathrm{R}$ " & HEX 5 Byte & ${ }^{\circ} \mathrm{C}$ \\
\hline 27 & 血圧測定時刻 & "S" & HEX 6 Byte & HHMMSS \\
\hline 28 & 最高血圧 & " $T "$ & HEX 5 Byte & $\mathrm{mmHg}$ \\
\hline 29 & 最低血圧 & "U" & HEX 5 Byte & $\mathrm{mmHg}$ \\
\hline 30 & 脈拍 & "V" & HEX 5 Byte & bpm \\
\hline 31 & 血圧警報 & "i" & HEX 1 Byte & \\
\hline
\end{tabular}



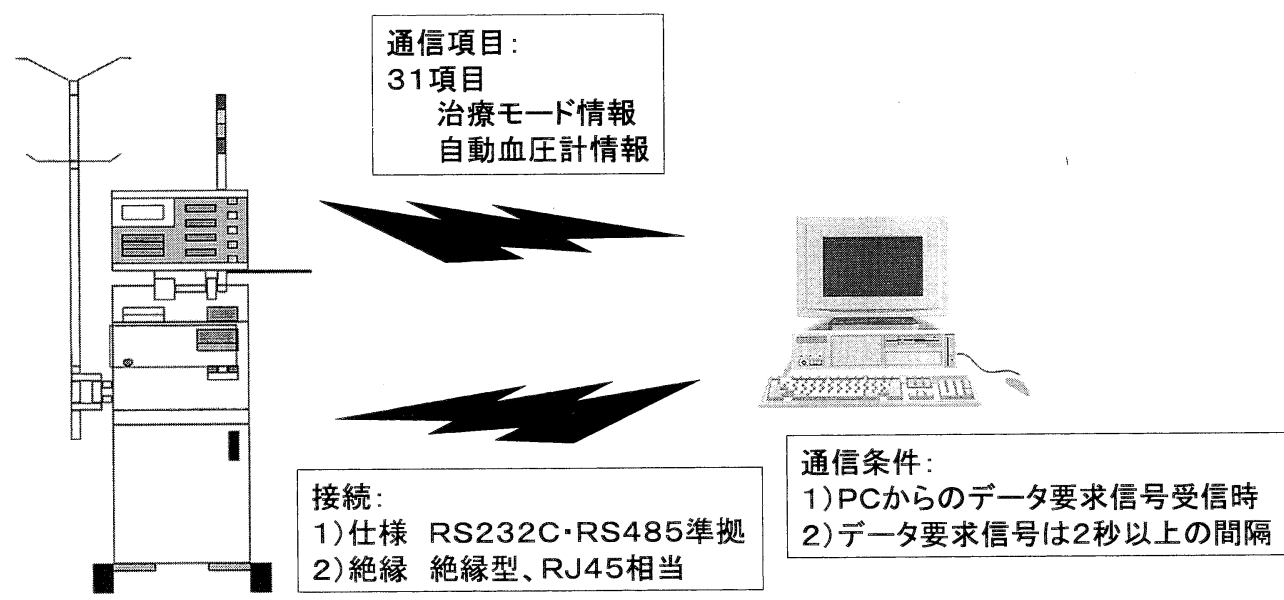

図 共通通信プロトコールバージョンアップの概要

とする。透析装置に内蔵される自動血圧計に限り情報 通信可能とした。

以上より，現状の通信項目に追加される送信データ は全 11 項目となり，例えば，治療プラグ，治療モード， $\mathrm{HDF} や \mathrm{HF}$ などに必要な補液目標值, 補液温度, 自動 血圧計の測定時間や測定值などである。また，血圧警 報が追加される（表）。

図に今回のバージョンアップを整理した。新たな通 信仕様・項目に対しては, 情報要求サンプリング信号 を2秒以上とし, HD 以外に ECUM, HDF, HF など の治療情報が通信項目に追加される。自動血圧計情報 取り込みは，透析装置に内蔵される自動血圧計のみ情 報通信を可能とする。透析装置と周辺機器の情報通信 は，今回のバージョンアップに含まない（将来の方向 性を考え継続議論とした). 通信の安全性は接続部分の 絶縁仕様を明確に仕様書 (案) に書き込むこととした。

\section{III. 今後の方向性}

今回のバージョンアップは従来システムの持つ問題 点のうち, 比較的速やかに対処可能な事柄を中心に改 良することを重点とした。本小委員会ワーキンググ ループの当面の目標は，透析装置の制御まで踏み込ん だ共通通信プロトコールを考えている。今後，このよ
うな各社透析装置の情報収集と制御を行う場合, 安全 性を最重点に考えなければならない。したがって，日 本透析医学会と医器工との間で透析装置の制御動作な どのシステムに関する安全性のガイドラインについて 充分な議論が必要となる。

日本透析医学会の立場を考えたとき，共通通信プロ トコールの基本コンセプトは各社の透析装置を一括管 理可能なシステムとすることである。さらに，透析装 置や周辺装置と情報交換可能なシステムが望まれる。 この基本コンセプトに沿って, 日本透析医学会は医器 工と協力体制を維持して行く考えである。将来, 日本 透析医学会と医器工の両者間で各社の透析装置を安全 に一括管理できたとき, 透析施設での省力化に透析装 置を選択する必要がなくなる。

\section{総括}

日本透析医学会, 学術委員会コンピュータ化検討小 委員会, ワーキンググループは, 厚生労働省が安心し て認可できる血液透析装置の共通通信プロトコールの 筋道を作ることが当面の役割と考える。今後は, 透析 装置の制御まで踏み込んだ共通通信プロトコール作り を考え進めなければならない。 